\title{
Occurrence and fate of antimony in plastics
}

Montserrat Filella

Department F.-A. Forel, University of Geneva, Boulevard Carl-Vogt 66, CH-1205 Geneva, Switzerland

Pierre Hennebert

INERIS (National Institute for Industrial Environment and Risks), BP 2, F-60550 Verneuilen-Halatte, France

Gudny Okkenhaug

Norwegian Geotechnical Institute (NGI), P.O. Box 3930 Ullevål Stadion, N-0806 Oslo, Norway

Norwegian University of Life Science (NMBU), Faculty of Environmental Sciences and Natural Resource Management, P.O. Box 5003, NO-1432 Ås, Norway

Andrew Turner

School of Geography, Earth and Environmental Sciences, Plymouth University, Drake Circus, Plymouth PL4 8AA, UK 


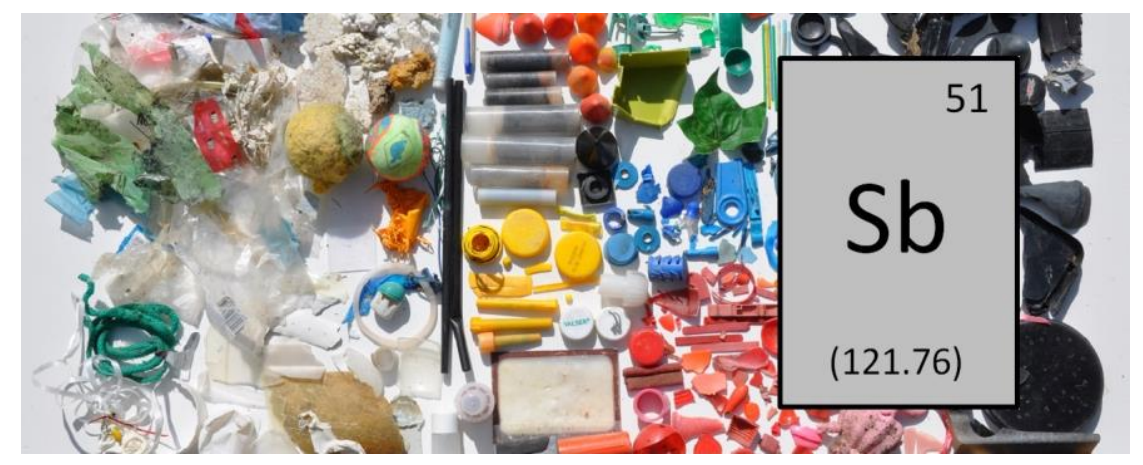

\title{
Highlights
}

- The presence and fate of $\mathrm{Sb}$ in plastics is discussed for the first time

- $\mathrm{Sb}$ is not recovered from plastics. Thus, $\mathrm{Sb}$ fate is entirely linked to their fate

- Data on Sb migration from manufactured objects largely missing

- Sb presence compromises the potential reuse of bottom incineration ashes

\begin{abstract}
Antimony ( $\mathrm{Sb})$ is a technology critical element whose presence is ubiquitous in manufactured products, and in particular in plastics where it is used extensively as a flame retardant synergist for brominated compounds, as a catalyst for polyethylene terephthalate production, and as a pigment for colour. This study reviews the usage, regulations and fate of $\mathrm{Sb}$ in plastics by examining primary data on its production, applications, contents in and migration from manufactured objects, and presence in and release from waste, including the disposal and recycling routes for this material (i.e., non-controlled disposal, incineration, landfilling and recycling). Consumption of $\mathrm{Sb}$ and the relative apportioning of the metalloid between different uses in plastics change continuously and are largely driven by dynamic economic factors; accordingly, reference to secondary data or sources can be misleading. Since Sb is not recovered from plastics, its fate is entirely linked to the fate of plastics themselves which, as far as disposal and recycling are concerned, might be dictated by the presence of coassociated regulated substances such as brominated flame retardants. Significantly, because of the high leachability of $\mathrm{Sb}$ from bottom incineration ashes, the EU considers the metalloid as the most problematic substance regarding the potential reuse of this material.
\end{abstract}


Keywords:

antimony production, antimony consumption, plastics, incineration, landfilling, 


\section{Introduction}

Antimony is in the 2017 list of Critical Raw Materials for the EU [1], and, although not considered critical in the US in the past [2], it has been included in the 2018 List of Critical Minerals [3]. Materials appearing on these lists have been identified as critical for the EU and US because of possible risks of supply shortage (scarcity) and because their impacts on the economy are higher than those of most of the other raw materials. Antimony is considered a critical material because it is nearly exclusively produced in China. End-of-life recycling input rate is $28 \%$ in Europe [1] but this arises mostly because of its use as a metal (or, strictly, a metalloid). Antimony cannot be recovered from plastics since it is generally dispersed at low concentrations in the polymeric matrix. Nevertheless, for the 'plastics community', the presence of $\mathrm{Sb}$ can be a nuisance because it can hinder plastic recycling or disposal and the reuse of bottom ashes resulting from waste incineration.

The main driver for the studies in the 'antimony community' is the possible toxicity and ecotoxicological effects derived from its presence in products in use, in legacy plastics, and in disposed (e.g. landfilled) materials. Toxicity concerns relate to antimony trioxide $\left(\mathrm{Sb}_{2} \mathrm{O}_{3}\right)$, the most commercially significant form of Sb. Some years ago, the International Agency for Research on Cancer (IARC) listed $\mathrm{Sb}_{2} \mathrm{O}_{3}$ as group 2B, "possibly carcinogenic to humans" [4]. Since the IARC evaluation, additional studies with $\mathrm{Sb}_{2} \mathrm{O}_{3}$ have revealed inconclusive or ambiguous results. Recently, the US National Toxicology Program (NTP) asserted that "... antimony trioxide is reasonably anticipated to be a human carcinogen based on sufficient evidence of carcinogenicity from studies in experimental animals and supporting evidence from mechanistic studies. The data available from studies in humans are inadequate to evaluate the relationship between human cancer and exposure specifically to $\mathrm{Sb}_{2} \mathrm{O}_{3}$ or antimony in general" [5].

Exposure to $\mathrm{Sb}_{2} \mathrm{O}_{3}$ is mainly in the work place but can also occur when consumer products containing the compound are used or while breathing contaminated air. Therefore, the interest in the presence of $\mathrm{Sb}$ in consumer products, which are mostly plastics, is increasing. It is surprising that there is a lack of exposure data from consumer products $[5,6]$, but even data on the occurrence and concentrations of $\mathrm{Sb}$ in plastics are scarce. In this study we aim to assess the presence and fate of Sb in plastics, as defined by the blue shaded area in Figure 1, but do not an attempt to establish a complete life cycle analysis or a mass balance evaluation of the metalloid. 


\section{Antimony production and uses}

For the production and uses of $\mathrm{Sb}$, we rely on USGS data (https://minerals.usgs.gov/minerals/pubs/commodity/antimony/). Other sources exist (e.g., Roskill) and values might not be entirely coincident but we consider the USGS to be the most reliable source for the scope of our study. (Note that the International Antimony Association (www.antimony.com) does not report these data.) According to the data, plotted in Figure 2, world Sb production steadily increased from the beginning of the $20^{\text {th }}$ century until 1980 , with two peaks coincident with the two World Wars. From 1980 to 2000 production at least doubled, but since then it has remained at between 150,000 and 200,000 $\mathrm{t} \mathrm{a}^{-1}$.

In plastics, $\mathrm{Sb}$ is encountered both as an additive (for flame retardancy or colour) and as catalytic residue from the manufacture of specific polymers. However, the recycling of plastics from one use or source to another may result in the wider contamination of products by $\mathrm{Sb}$ at lower concentrations [7,8]. As a catalyst, the most important use of $\mathrm{Sb}$ is in the production of the polyester thermoplastic, including polyethylene terephthalate (PET). This polymer is used in textiles and for the storage or packaging of food and drinks and $\mathrm{Sb}$ residues arising from the use of $\mathrm{Sb}_{2} \mathrm{O}_{3}$ or antimony triacetate $\left(\mathrm{Sb}\left(\mathrm{CH}_{3} \mathrm{CO}_{2}\right)_{3}\right)$ are usually present at concentrations of a few hundred $\mathrm{mg} \mathrm{kg}^{-1}$ [9].

The trioxide of antimony is often added to plastic casings of heat-generating electrical products as a flame retardant synergist. Typically, $\mathrm{Sb}_{2} \mathrm{O}_{3}$ is added in combination with halogenated (mainly brominated) flame retardants and antimony oxyhalides generated in the gas phase act as free radical scavengers, with the ratio of $\mathrm{Br}: \mathrm{Sb}$ in most products in the range 2:1 to 3:1 [10] and the content of $\mathrm{Sb}_{2} \mathrm{O}_{3}$ ranging from about $1 \%$ by weight in $\mathrm{PVC}$ to $30 \%$ in some specialist rubbers [9]. The trioxide performs well in most plastics but in PET it may act as a depolymerisation catalyst; here, therefore, other compounds of antimony, like sodium antimonite, are used as flame retardant synergists.

As a very fine white powder, $\mathrm{Sb}_{2} \mathrm{O}_{3}$ is also sometimes used to pigment polymers for specialised applications [11]. More important as a pigment, however, $\mathrm{Sb}$ is a component of many rutile forms of complex inorganic compounds that are used in plastics [12]. These include nickel antimony titanium yellow (pigment yellow 53; (Ti,Ni,Sb) $\mathrm{O}_{2}$ ), chrome antimony titanium yellow (pigment brown 24; $\left.(\mathrm{Ti}, \mathrm{Cr}, \mathrm{Sb}) \mathrm{O}_{2}\right)$, manganese antimony titanium brown (pigment yellow 164; $(\mathrm{Ti}, \mathrm{Mn}, \mathrm{Sb}) \mathrm{O}_{2}$ ) and manganese chrome antimony brown (pigment brown 40; (Ti,Mn, $\mathrm{Cr}, \mathrm{Sb}) \mathrm{O}_{2}$ ). Such pigments have excellent fastness properties, and 
are durable, chemically resistant and thermally stable up to $1000^{\circ} \mathrm{C}$. Their use has increased over the past two decades, especially in polyolefins and acrylonitrile-butadiene-styrene (ABS), because $\mathrm{Cd}$ - and $\mathrm{Pb}$-based alternatives have been phased out on safety and environmental grounds. Figure 3 compares x-ray fluorescence (XRF) spectra from yellow ABS Lego bricks manufactured in about 1995 and about 1980 that demonstrate a clear shift from Cd-based pigments to those containing $\mathrm{Sb}$ and $\mathrm{Ti}$ in what is essentially the same product.

Information on US Sb consumption in different applications (metal, flame retardants and non-metallic applications other than flame retardants) is available since 1943 (Figure 4a) and in which matrices flame retardants have been used since 1974 (Figure 4b) (https://minerals.usgs.gov/minerals/pubs/commodity/antimony/). US data show that flame retardant synergists represent an important component of $\mathrm{Sb}$ usage, and in particular in plastics (a total of 2440 tonnes (t) in 2015 with $76.9 \%$ added to plastics, 15.7\% to textiles, $5.3 \%$ to rubber and $2.1 \%$ to adhesives), but the percentage of this application has clearly decreased between 1995 and 2015 (from 55\% to 35\% of all Sb use). Other uses of Sb in plastics include pigments and, as $\mathrm{Sb}_{2} \mathrm{O}_{3}$, the principal catalyst for the production of polyester fibre and for PET production.

Data available for Europe for 2005 are given in [6] and cited in [13], which presumably means that more recent quantitative information is not available. Values are difficult to compare with those from the US because data are older and the production and usage of $\mathrm{Sb}$ is very dynamic. Moreover, the precise categories referred to in Europe and the US are different. Thus, about 24,000 $\mathrm{t}$ of $\mathrm{Sb}$ were used in the EU in 2005 with the following distribution: as a flame-retardant in plastics (9200 t), PVC (8800 t), rubber $(2200 \mathrm{t})$ and textiles (1750 t); as a catalyst in PET production (950 t); as an additive in glass manufacture $(250 \mathrm{t})$; and in pigments, paints and ceramics (1100 t).

\section{Plastic production}

According to a recent study by Geyer et al. [14], the total amount of fibres and resins produced from 1950 through 2015 world-wide is 7,800 Mt, with $50 \%$ of the plastic produced in the last 13 years of the period considered. When additives are accounted for, the total weight increases to $8,300 \mathrm{Mt}$. According to the same authors, approximately 6,300 Mt of plastic waste have been generated in the same period, around $9 \%$ of which has been recycled, 
$12 \%$ incinerated and 79\% discarded (i.e., accumulated in landfills or lost in nature); therefore, the in-use stocks are estimated at 2,500 Mt.

The distribution of non-fibrous plastics produced is as follows: polyethylene (PE) 36\%, polypropylene (PP) 21\%, and polyvinyl chloride (PVC) 12\%; PET, polyurethane (PUR) and polystyrene (PS) contribute $<10 \%$ each. Polyester, most of which is PET, accounts for $70 \%$ of all fibrous plastics (polyester, polyamide, and acrylic).The distribution by usage indicates that $42 \%$ of all non-fibrous plastics have been employed for packaging (predominantly PE, PP and PET) while the construction sector has used 69\% of all PVC produced or in stock. When making comparisons, however, it is also important to consider product life-times as packaging is largely consumed in the same year but construction materials may last for decades.

\section{Measurements of antimony in plastics}

Over the past few years, the authors have generated an extensive dataset of $\mathrm{Sb}$ in consumer plastics [15-17] and in beached marine and lacustrine litter [18,19] generated by energydispersive portable x-ray fluorescence spectrometry. Specifically, a Niton XL3t instrument has been deployed in situ or in an accessory stand using a low density plastics mode and with appropriate thickness correction. The data reveal how widely $\mathrm{Sb}$ is encountered in plastics and in a range of concentrations that spans several orders of magnitude (from the detection limit of the instrument of a few tens of $\mathrm{mg} \mathrm{kg}^{-1}$ to about $10 \%$ by weight). Overall, $\mathrm{Sb}$ was detected in about $15 \%$ of several thousand consumer items analysed, and was most abundantly encountered in electrical equipment and items of (polyester) clothing. A careful examination of the data reveals that the occurrence of $\mathrm{Sb}$ can be linked with either its different uses or the recycling of plastic, as summarised in Table 1. Here, the different sources of $\mathrm{Sb}$ are shown with concentration ranges of the metalloid in the plastics, concentrations of $\mathrm{Br}$ as an indicator of the presence or content of halogenated flame retardant content, typical colours of the plastic and examples of the type of product where it is often found. Note that the categories or sources are not necessarily mutually exclusive in that some flame retarded materials or PET products could also be pigmented with Sb while pigmented products could be derived from recycled electrical waste.

Briefly, $\mathrm{Sb}$ is found in a variety of PET- or polyester-based products of any colour at concentrations $<1000 \mathrm{mg} \mathrm{kg}^{-1}$ and in the absence of detectable $\mathrm{Br}$ as catalytic residue, while higher $\mathrm{Sb}$ concentrations are encountered in yellow, brown and green products and in the 
absence of $\mathrm{Br}$ as a pigment. In electrical equipment, both old and new, $\mathrm{Sb}$ may be found as a synergist at concentrations above $5000 \mathrm{mg} \mathrm{kg}^{-1}$ and usually in the presence of $\mathrm{Br}$ at similar or greater concentrations. In PVC electrical (and some non-electrical) products, $\mathrm{Sb}$ is encountered at concentrations $>5000 \mathrm{mg} \mathrm{kg}^{-1}$ but in the absence of detectable $\mathrm{Br}$ (where $\mathrm{Cl}$ as a component of the polymer acts as an inherent flame retardant).

\section{Release of $\mathrm{Sb}$ from plastics during use}

Shotyk et al. [20] first provided evidence of Sb leaching from PET bottles into contained water when the element was measured in 132 brands of bottled water from 28 countries. Hansen and Pergantis [21] determined $\mathrm{Sb}$ in a selection of different juices packed in either bottles of PET or other commonly used container materials. Here, the driver for the research was that fruit juices contain high amounts of organic acids, such as citric, malic and ascorbic, which are known to be efficient complexants of $\mathrm{Sb}$ (III). Juices bottled in PET contained more $\mathrm{Sb}$ than those bottled in Tetra Pak, glass containers or aluminium cans but always, as was the case of Shotyk's study, below regulatory values for drinking water $\left(5 \mu \mathrm{g} \mathrm{L}^{-1}\right.$ in Europe [22] and in China [23]) and the USEPA maximum contaminant level (MCL) of $6 \mu \mathrm{g} \mathrm{L}^{-1}$ [24]). Shotyk and co-workers' article [20] triggered the publication of many studies examining Sb contents in bottled waters that, more than 10 years later, continue to be regularly published. Among these studies, many different environmental factors have been identified that affect the amount of $\mathrm{Sb}$ released. For instance, concentrations were found to increase by $90 \%$ on average in 48 brands of bottled drinking water after a period of 6 months' storage at room temperature [25], with leaching from PET into water subsequently found to increase rapidly during an initial storage period and then the attain a steady state [26] Temperature has an effect on the release of Sb from PET [26-28], and greater release due to low $\mathrm{pH}$ has also been observed [28] and subsequently confirmed by a dissolution rate that is greater into sparkling water than into still water [26]. In contrast, PET exposure to sunlight appears to be of lesser significance to $\mathrm{Sb}$ migration [26,28], while contradictory conclusions have been reached regarding the effect of bottle colour on release [27,29]. Westerhoff et al. [27] and more recent publications [30-33] have also found that the extent of Sb leaching from PET containers from different manufacturers or mineral water brands can differ by an order of magnitude in experiments conducted under the same experimental conditions, thus casting doubts about the ability to make generalisations of $\mathrm{Sb}$ mobilisation. 
In the European Union, the conformity of a plastic material that comes into contact with food is covered by the 10/2011 Regulation [34] that is based on migration tests. Specific migration limits (SML) are provided for some substances, including antimony trioxide whose SML is $0.04 \mathrm{mg} \mathrm{Sb}$ per $\mathrm{kg}$ of food. Migration of $\mathrm{Sb}$ from PET containers into regulated EU food simulants, oil and vinegar has been determined and found to be far below the SML [35].

In contrast with the interest in Sb release from PET, the scarcity of data on Sb release from other polymers is striking, particularly when the current interest in the study of the environmental behaviour and potential (eco)toxicity of the metalloid stems from its alleged and well-publicised implication in SIDS (Sudden Infant Death Syndrome) in the late 90s (through use in cot mattresses [36,37]). This scarcity is confirmed by the recent NTP report on $\mathrm{Sb}_{2} \mathrm{O}_{3}$ carcinogenicity [5] referring to the above-mentioned EU 2008 report [6] as the only source to estimate consumer exposure to $\mathrm{Sb}$ from products containing $\mathrm{Sb}_{2} \mathrm{O}_{3}$. Note that NTP gives 'non determined values' for two of the four exposure pathways considered: sitting on flame-retardant-treated upholstery (dermal) and sucking on toys (oral).

As a pigment, flame retardant synergist or residue from recycling, $\mathrm{Sb}$ may occur in a variety of plastic toys. The original European Council Directive 88/378/EEC on toy safety [38] stipulated a limit of $60 \mathrm{mg} \mathrm{kg}^{-1}$ migratable $\mathrm{Sb}$, where migration was defined by two-hour extraction in dilute $\mathrm{HCl}$ at $37{ }^{\circ} \mathrm{C}$. An amended directive, applied to toys placed on the market from July 2013, provided revised limits on migration that were specific to the type of matrix involved [39]; specifically, liquid or sticky $=11.3 \mathrm{mg} \mathrm{kg}^{-1}$; brittle, powder-like or pliable $=45$ $\mathrm{mg} \mathrm{kg}^{-1}$; material that can be scraped off $=560 \mathrm{mg} \mathrm{kg}^{-1}$. Recent application of the migration test to old plastic toys revealed compliance in all cases, with a maximum migration of about $100 \mathrm{mg} \mathrm{kg}^{-1}$ from beaded jewellery [17].

In a recent extensive survey of sludges and effluents of 64 Swiss wastewater treatment plants [40], the median Sb concentration in effluents was $1.0 \mu \mathrm{g} \mathrm{L}^{-1}$, a concentration clearly higher than in European freshwaters (median value: $0.070 \mu \mathrm{g} \mathrm{L}^{-1}, n=807$ ) [37]. Likewise, the median $\mathrm{Sb}$ concentration in sludges, $3 \mathrm{mg} \mathrm{kg}^{-1}$, is considerably higher than in the Upper Continental Crust (UCC) (0.75 $\left.\mathrm{mg} \mathrm{kg}^{-1}\right)$ [41] and in European soils (median: $0.470 \mathrm{mg} \mathrm{kg}^{-1}, n$ = 783) [42]. It is impossible to know which part of the anthropogenic contribution comes from plastics and which is from the presence of $\mathrm{Sb}$ in other matrices but the data suggest that the use of $\mathrm{Sb}$ is associated with a measurable release of the element and, given its extensive presence in plastics, there is no reason to think that they do not contribute 
6. Where does antimony in plastics go 'after use'?

\section{1 'Lost in nature'}

The fate of Sb in plastics 'after use' is directly linked to plastics end-of-life. Geyer et al. [14] estimated that around $4900 \mathrm{Mt}$ of all plastics ever produced have been discarded and are accumulating in landfills or in the natural environment. It is impossible to estimate the amount that has not been disposed of in a controlled way but observations, mainly in the oceans, point to a significant amount of plastics having been mismanaged. For instance, plastic waste inputs from land into the ocean have been estimated at 4.8 to $12.7 \mathrm{Mt}$ for 2010 [43]. Increasing attention has been paid to particles known to be of a few millimetres down to micrometres in size, with research into the environmental presence and impact of these 'microplastics' in marine and freshwater environments accelerating in recent years.

Antimony concentrations were recently determined in beached plastics collected from the shores of Lake Geneva, Switzerland [19]. Antimony was detected in $11 \%$ of the 670 plastics measured, with a median concentration of $183 \mathrm{mg} \mathrm{kg}^{-1}$ (range: $33.1-27,100 \mathrm{mg} \mathrm{kg}^{-1}$ ). Plastics containing measurable $\mathrm{Sb}$ concentrations seem to be less abundant on ocean beaches, with the element only present in 5 out of 149 plastics collected from Whitsand Bay, southwest England, and a median concentration of $228 \mathrm{mg} \mathrm{kg}^{-1}$ (range: $154-6260 \mathrm{mg} \mathrm{kg}^{-1}$ ) [18].

\subsection{Antimony in waste}

In Europe, waste containing $\mathrm{Sb}$ is defined and classified by various regulations. According to the Classification, Labelling and Packaging regulations [44], waste is hazardous through the suspected carcinogenetic properties of $\mathrm{Sb}$ (IARC group 2B) if the concentration of $\mathrm{Sb}_{2} \mathrm{O}_{3}$ is $\geq$ $0.1 \%$ (equivalent to a concentration of $\mathrm{Sb}$ of $\geq 0.08 \%$ ). In the $\mathrm{EU}, \mathrm{Sb}$ is also classified as a 'heavy metal' and waste is 'ecotoxic', or poses an immediate or delayed risk to one or more sectors of the environment, if concentrations of all heavy metals, including $\mathrm{Sb}$, exceed certain thresholds $[45,46]$. If $\mathrm{Sb}$ were the sole contributor to toxicity, waste would be ecotoxic if the concentration of $\mathrm{Sb}_{2} \mathrm{O}_{3}$ exceeds $2.5 \%$. While this limit is not expected in most plastics, it must be appreciated that many end-of-life products containing high concentrations of $\mathrm{Sb}$ also contain brominated flame-retardants. Such waste would, therefore, be classified according to regulations governing these additives [47]. 
Although $\mathrm{Sb}$ is not included in the current RoHS (Restriction of Hazardous Substances) Directive $[48,49]$, nor in the Waste Electrical and Electronic Equipment (WEEE) Directive [50]. Antimony trioxide is one of the seven substances currently being assessed in the review of the list of restricted substances under RoHS 2 (RoHS Pack 15) [51]. Nevertheless, because of the sorting practices of WEEE and the inability to recover $\mathrm{Sb}$ from plastics on an industrial scale, $\mathrm{Sb}$ in WEEE is expected to share similar fates to many brominated compounds used as flame retardants. These include the incidental and unintended recycling of the metalloid into new consumer goods as described above, a process that has resulted from the exportation of WEEE and other materials from Europe and the US to countries in south east Asia and Africa that also manufacture plastic products $[15,16]$.

\subsubsection{Incineration}

The practice of end-disposal of municipal waste, either by incineration (waste-to-energy, WTE) or landfilling, varies considerably among different countries and regions. In the EU, the focus has been on reducing the fractions disposed of at landfills, with the preferred option being waste incineration. In the US in 2015, $12.8 \%$ of municipal solid waste (MSW) was incinerated and $52.5 \%$ was landfilled, but the trend reveals a gradual shift from landfilling to incineration [52]. Urbanization is growing in China, and WTE incineration is going to play an increasingly important role in the country's waste management [53].

Older studies have reported $\mathrm{Sb}$ concentrations in MSW of about $10 \pm 60 \mathrm{mg} \mathrm{kg}^{-1}$ [54]. In a comprehensive literature review from 2016, Götze and co-workers examined almost 100 publications globally (period 1990-2014) on the physical and chemical composition of individual waste material fractions [55]. The highest median $\mathrm{Sb}$ concentrations were found in the waste 'plastic' fraction $\left(24 \mathrm{mg} \mathrm{kg}^{-1}\right.$; containing different plastic products and polymer types, and including plastic packaging and household items) and a 'mix' fraction (or residual MSW; $62.9 \mathrm{mg} \mathrm{kg}^{-1}$ ) (Figure 5). These waste fractions would also be the most relevant for waste incineration, in addition to a 'combustibles' fraction (median concentration $=6.2 \mathrm{mg}$ $\mathrm{kg}^{-1}$ ). As described in section 4.1, substantially higher $\mathrm{Sb}$ concentrations (> $5000 \mathrm{mg} \mathrm{kg}^{-1}$ ) may occur in individual plastic products which eventually end up as waste.

Paoletti et al. [56] compared the industrial application of $\mathrm{Sb}$ compounds with the $\mathrm{Sb}$ contributions of solid waste fractions, and speculated that the element entering a waste combustion plant will be present mainly as trioxides, pentoxides and antimonates, with the 
main contribution coming from plastics, including WEEE that has been improperly disposed of. During incineration of municipal waste, approximately $20-40 \%$ of the waste content is converted to bottom ash and $2-8 \%$ ends up in the air pollution control (APC) system (hereafter referred to as fly ash) [54,57]. Thermodynamic calculations predict a high volatility of $\mathrm{Sb}$ during solid waste incineration and that nearly all $\mathrm{Sb}$ entering the combustion chamber would be volatilized and leave the chamber along with the flue gas [56]. However, previous studies on the behaviour of Sb during incineration shows that about one half of the of $\mathrm{Sb}$ ends up in bottom ash with the remainder (33 to 75\%) ending up in the fly ash or emitted to air [56,58-60]. The distribution is dependent on the type of waste, combustion temperature and occurrence of other elements, with chlorine in particular (e.g. through addition of PVC) promoting antimony volatilization [56,61]. Studies carried out by Paoletti et al. (2001) show that a possible reason for the fixation of antimony in the bottom ashes could be the presence of antimonates in the fuel bed or their formation arising from interactions with other chemical compounds like calcium oxide [56].

Fly ash is often defined as hazardous waste due to its content of soluble salts, potentially toxic metals and trace organic pollutants, and its high $\mathrm{pH}$ in contact with water. Although most of the fly ash generated globally is currently landfilled, with or without prior treatment $[62,63]$, there is increasing focus on resource recovery of this residue [60]. Bottom ash from municipal solid waste incineration is generally considered as non-hazardous waste, and in many countries is disposed of at non-hazardous waste landfills or recovered as construction material in engineering applications (bulk fill, roads, embankments, substitute aggregate). Due to increased landfill costs and the push towards a circular economy, bottom ash is often regarded as an underutilized secondary source whose recovery should be increased $[6,64,65]$.

NOAH Langøya (Norway) annually treats approximately 300,000 t of waste incineration fly ash originating from Norway, Sweden and Denmark. Antimony analysis of nearly 2000 fly ash samples in the period 2007 - 2017 revealed variable concentrations with a median of 470 $\mathrm{mg} \mathrm{kg}{ }^{-1}$ (average $=610 \pm 2342$ ). These values are consistent with previously reported concentration ranges in waste incineration fly ash (340-1016 mg kg-1) given in the literature $[54,66]$, as well as data from INERIS (median $=322 \mathrm{mg} \mathrm{kg}^{-1} ; n=810$; INERIS, unpublished) and values reviewed by Cornelis et al. (2008) (80 and $\left.1000 \mathrm{mg} \mathrm{kg}^{-1}\right)$ [67].

In a Swedish study on $\mathrm{Sb}$ in 31 energy waste ashes, the average concentration of the metalloid in fluidized bed incinerator fly ash and grate boiler fly ash was 192 and $1140 \mathrm{mg}$ 
$\mathrm{kg}^{-1}$, respectively, revealing substantial differences between the two incineration technologies regarding the fate of the element during incineration [58]. A similar difference was shown in a Japanese study of fly ash samples from 26 WTE plants, with an average Sb concentration in fly ash from fluidized bed and grate boiler (stoker) incinerators of $155 \pm 45(n=7)$ and 435 $\pm 81(\mathrm{n}=19) \mathrm{mg} \mathrm{kg}^{-1}$ respectively [68]. By comparison, considerably lower Sb concentrations in MSWI fly ash have been reported from studies in China, varying between 23 and $197 \mathrm{mg}$ $\mathrm{kg}^{-1}[69,70]$.

Statistical analysis of the NOAH Langøya data indicates that there is a slight decrease (MannKenndal test: $\mathrm{Z}=-3.37$, Sens slope: $11 \mathrm{mg} \mathrm{kg}^{-1} \mathrm{y}^{-1}$ ) in $\mathrm{Sb}$ fly ash concentrations from 2006 to 2017 (Figure 5). This is consistent with data for the Nordic countries on the total use of $\mathrm{Sb}_{2} \mathrm{O}_{3}$ in products that indicates an overall decline in the period 2000 - 2016 (http://spin2000.net/). It has been suggested by the European Semiconductor Industry Association, ESIA, that a decline might be a result of efforts aimed at reducing the use of $\mathrm{Sb}_{2} \mathrm{O}_{3}$ as a synergist in association with brominated flame retardants [13]. However, it is uncertain if this trend and the reason behind it are representative of other regions.

Annex II to Directive 1999/31/EC gives leaching limit values for Sb from waste acceptable at landfills for inert, ordinary and hazardous waste [71]. Antimony leaching limits for hazardous waste landfills are $1.0 \mathrm{mg} \mathrm{L}^{-1}$ (standard up-flow column test, EN 14405) and $5 \mathrm{mg} \mathrm{kg} \mathrm{kg}^{-1}$ (standard batch test, EN 12457; liquid-solid ratio (L/S) of 10), respectively. Routinely standard batch tests (L/S of 10) on untreated fly ash at NOAH Langøya (period 2008 - 2013, $n=168)$ show an average $\mathrm{Sb}$ concentration of $1.28 \pm 1.66 \mathrm{mg} \mathrm{kg}^{-1}$ [72], which is below the criterion for hazardous waste. In an experimental study on waste incineration fly ash, Okkenhaug et al. [73] showed a low water leachability of $\mathrm{Sb}$ at natural $\mathrm{pH}$ (11-12), but a strong inverse dependence of migration on $\mathrm{pH}$. This study also demonstrated that $\mathrm{Sb}$ occurred exclusively in the pentavalent form in the water phase [73].

Antimony concentrations measured in waste incineration bottom ash are substantially lower than concentrations in fly ash. In a study covering 18 waste incineration plants in Norway, the average $\mathrm{Sb}$ concentration in fresh bottom ash was $85 \pm 25 \mathrm{mg} \mathrm{kg}^{-1}$ [74] and in the same range as reported for bottom ashes from waste incineration in Sweden (means of 61.8 and $86.5 \mathrm{mg} \mathrm{kg}^{-1}$ for great bottom ash and fluidized bed ash, respectively; [58]). By comparison, the average $\mathrm{Sb}$ concentration in bottom ash from The Netherlands has been reported as $34 \mathrm{mg}$ $\mathrm{kg}^{-1}[66]$. 
In a study on incineration of wastes containing $\mathrm{Sb}$ in fluid bed boilers, high leakage of the element from bottom ash is reported [75]. Standard leaching batch tests with water (L/S 10 batch test, $24 \mathrm{~h}$ shaking) of bottom ashes on 14 Norwegian fresh bottom ashes showed an average migratable concentration of $0.39 \pm 0.26 \mathrm{mg} \mathrm{kg}^{-1}$, which is below the European leaching limit for ordinary waste landfills of $0.7 \mathrm{mg} \mathrm{kg}^{-1}$ but exceeds the leaching limit for inert waste landfills of $0.06 \mathrm{mg} \mathrm{kg}^{-1}$ [74]. The same type of leaching test carried out on bottom ashes in Sweden resulted in average values ranging between 0.175 and $0.199 \mathrm{mg} \mathrm{kg}^{-1}$ for great bottom ash and boiler ash, respectively [58]. Storage of the bottom ash increases the leachability [74], possibly due to carbonization and a subsequent $\mathrm{pH}$ decrease leading to a dissolution of Sb containing minerals (ettringite and romeites) [64,76]. Because the leaching of $\mathrm{Sb}$ from bottom ashes has proven difficult to reduce through various methods tested, the $\mathrm{EU}$ considers $\mathrm{Sb}$ as the most problematic substance in ashes from municipal incinerators as regards possible reuse, imposing more general constraints on the recovery potential of the waste material $[6,64,77]$.

Data on $\mathrm{Sb}$ emissions to air from incineration of waste are scarce. A literature review carried out by the EU indicates that $0.1-1 \%$ of the $\mathrm{Sb}$ in MSW that was incinerated is emitted to the atmosphere [6]. In a comprehensive global inventory of atmospheric Sb emissions from anthropogenic activities, Tian et al. [78] estimate that waste incineration ranks as the second largest $\mathrm{Sb}$ emission source to the environment, contributing about $23.9 \%$ to the global emissions in 2010.

\subsubsection{Landfilling}

Emissions of $\mathrm{Sb}$ from landfills are mainly related to leachate water and atmospheric discharges (landfill gasses), with the former route considered to be the most important [6]. Landfill leachate is mainly generated because of the percolation of water through the landfill body due to precipitation or infiltration of groundwater or surface water. Depending on infiltration and interception of water, landfills can produce high quantities of leachate water. Moreover, depending on the closure technology and reduction of infiltration of external water, many landfills will still produce leachate water post-closure, with the makeup of the waste and landfill body conditions (e.g. $\mathrm{pH}$, redox conditions, temperature) determining leachate composition. The presence of $\mathrm{Sb}$ in leachate water is related to the aggregated content of all waste containing the element in different forms. Based on potential leaching of 
various waste fractions, the presence of plastics and bottom ash from waste incineration are believed to be the most significant waste fractions [79].

Quantitative information about $\mathrm{Sb}$ in leachate water from landfills are scarce. Kiddee et al. [80] carried out a survey of four selected MSW landfills (also including WEEE) in an arid region of South Australia and found $\mathrm{Sb}$ concentrations varying between $1.4 \pm 0.8$ and $13 \pm 6$ $\mu \mathrm{g} \mathrm{L}^{-1}$ in fresh leachate. Antimony concentrations measured in municipal landfill leachates in Norway $(n=26)$ in the period 2007 - 2013 were between 0.1 and $9 \mu \mathrm{g} \mathrm{L}^{-1}$ [81], with more comprehensive studies encompassing 40 years of operation (1968-2008) showing Sb concentrations ranging from 0.2 to $12 \mu \mathrm{g} \mathrm{L}^{-1}$ (Figure 7) [81]. In a study on municipal landfill leachate from various facilities in Sweden, Öman et al. [82] found Sb concentrations ranging from 0.82 to $1.7 \mu \mathrm{g} \mathrm{L}^{-1}(n=3)$. These data are consistent with those reported by Looser and co-workers [83] in landfill leachate from 41 landfills (six were MSW landfills) in Switzerland, Italy and France, with $10-90 \%$ percentiles of Sb concentrations of 0.1 and $1.5 \mu \mathrm{g}$ $\mathrm{L}^{-1}$, respectively. One review in the literature for municipal waste landfills reported a range of Sb concentrations of 0-3190 $\mu \mathrm{g} \mathrm{L}^{-1}$ [84], suggesting that some landfills can have substantially larger leachable $\mathrm{Sb}$ contents than the facilities referred to above.

Landfill leachate may either be treated on site, transferred to an off-site municipal sewage plant or discharged directly to surface water [6]. On-site treatment of leachate water by aerated lagoon and sedimentation (site $\mathrm{A}$ and $\mathrm{B}$ ) and membrane filtration (site $\mathrm{C}$ ) may reduce the Sb concentrations, as exemplified in Figure 7 [81].

\section{Summary}

As a potentially toxic technology critical element, $\mathrm{Sb}$ has received increasing scientific and regulatory attention over the past two decades. Antimony occurs widely in plastics and at concentrations ranging from a few tens of $\mathrm{mg} \mathrm{kg}^{-1}$ to about $10 \%$ by weight in the form of a flame retardant synergist with brominated compounds or in PVC, a catalytic residue arising from the manufacture of PET, and a pigment. Because technology is currently unavailable for the recovery of $\mathrm{Sb}$ from plastics, the metalloid is widely dispersed in products derived from recycling, and in particular those recycled form waste electronic plastic. Consumption of $\mathrm{Sb}$ and its relative apportioning between these and other (non-plastic) uses change continuously and are largely dependent on economic considerations, with the use of secondary or outdated sources of data providing potentially misleading conclusions. 
Despite a co-association with $\mathrm{Br}$ in electronic plastics and products recycled therefrom, $\mathrm{Sb}$ is not included in the RoHS Directive; however, concentrations in or migration from other consumer plastics like food-contact items and toys are regulated, as are concentrations related to the municipal waste stream. With shifts in the disposal of waste towards incineration, coupled with an apparent chemical suppression of the volatility of the element during this process, a concern is the occurrence and leachability of $\mathrm{Sb}$ from bottom ash as this can impose constraints on the recovery of the material for reuse. The ubiquity of $\mathrm{Sb}$ in plastics through recycling also ensures that it is a pervasive contaminant of marine and freshwater litter where its impacts and fate are largely unknown.

CRediT author statement

Montserrat Filella: Conceptualization, Investigation, Writing, Visualisation. Pierre Henebert: Investigation, Writing. Gudny Okkenhaug: Investigation, Writing, Visualisation. Andrew Turner: Investigation, Writing, Visualisation, Reviewing and editing.

\section{Declaration of interests}

The authors declare that they have no known competing financial interests or personal relationships that could have appeared to influence the work reported in this paper.

\section{Acknowledgements}

We thank Kateryna Klochko and Sarah Jane White from the US Geological Survey for their willingness to help us to understand the complexities and caveats of US Sb production data available at https://minerals.usgs.gov/minerals/pubs/commodity/antimony/. We also thank Trond Maehlum at NIBIO for sharing valuable landfill leachate data, and Sverre Koren and Tone Klufthaugen at NOAH for sharing information from their extensive database on fly ash. 


\section{References}

[1] European Commission, Communication from the Commission to the European Parliament, the Council, the European Economic and Social Committee and the Committee of the Regions on the 2017 list of Critical Raw Materials for the EU. COM(2017) 490 final, Brussels, 2017.

[2] US Department of Energy, Critical Materials Strategy, Washington DC, US, 2011. Available at: https://www.energy.gov/sites/prod/files/DOE_CMS2011_FINAL_Full.pdf. Last accessed: 24 April 2019.

[3] US Office of the Secretary of the Department of the Interior, Final List of Critical Minerals 2018, Federal Register 83 (No. 97) (2018) 23295.

[4] IARC, Antimony trioxide and antimony trisulfide. In: Some Organic Solvents, Resin Monomers and Related Compounds, Pigments and Occupational Exposures in Paint Manufacture and Painting. IARC Monographs on the Evaluation of Carcinogenic Risks to Humans, Volume 47 (1989) 291-305.

[5] NTP, Report on Carcinogens Monograph on Antimony Trioxide October, Office of the Report on Carcinogens, National Toxicology Program, National Institute of Environmental Health Sciences, National Institutes of Health, Research Triangle Park, US, 2018.

[6] European Communities, ECB. European Union Risk Assessment Report. Diantimony trioxide. DRAFT. CAS No: 1309-64-4. EINECS No: 215-175-0. RISK ASSESSMENT Sweden, 2008.

[7] A. Alassali, M. Abis, S. Fiore, K. Kuchta, Classification of plastic waste originated from waste electric and electronic equipment based on the concentration of antimony, J. Hazard. Mat. 380 (2019) 120874, doi:10.1016/j.jhazmat.2019.120874

[8] V. Intrakamhaeng, K.A. Clavier, Y. Liu, T.G. Townsend, Antimony mobility from Ewaste plastic in simulated municipal solid waste landfills, Chemosphere 241 (2020) 125042, doi:10.1016/j.chemosphere.2019.125042 
[9] D. Dupont, S. Arnout, P.T. Jones, K. Binnermans, Antimony recovery from end-oflife products and industrial process residues: A critical review, J. Sustainable Metallurgy 2 (2016) 79-103, doi:10.1007/s40831-016-0043-y

[10] E.S. Papazoglou, Flame retardants for plastics, in: C.A. Harper (ed.), Handbook of Building Materials for Fire Protection, McGraw-Hill, New York, 2004.

[11] J.W. Gooch, Analysis and Deformulation of Polymeric Materials: Paints, Plastics, Adhesives, and Inks, Kluwer Academic, New York, 2006.

[12] G. Rangos, Inorganic colored pigments, in: R.A. Charvat (Ed.), Coloring of Plastics: Fundamentals, 2nd Edition, John Wiley, Hoboken, NJ, 2004.

[13] Oeko-Institut e.V., First Stakeholder Consultation - Compilation of initial substance information for diantimony trioxide. http://rohs.exemptions.oeko.info/fileadmin/user_upload/RoHS_Pack_15/Diantimonytrioxide_Substance_info_1st_cons_Pack-15.pdf

[14] R. Geyer, J.R. Jambeck, K. Lavender Law, Production, use, and fate of all plastics ever made, Sci. Adv. 3 (2017) e1700782. doi:10.1126/sciadv.1700782

[15] A. Turner, M. Filella, Field-portable-XRF reveals the ubiquity of antimony in plastic consumer products, Sci. Total Environ. 584-585 (2017) 982-989, doi:10.1016/j.scitotenv.2017.01.149

[16] A. Turner, M. Filella, Bromine in plastic consumer products - Evidence for the widespread recycling of electronic waste, Sci. Total Environ. 601-602 (2017) 374-379, doi:10.1016/j.scitotenv.2017.05.173

[17] A. Turner, Concentrations and migratabilities of hazardous elements in second-hand children's plastic toys, Environ. Sci. Technol. 52 (2018) 3110-3116, doi:10.1021/acs.est.7b04685

[18] A. Turner, K.R. Solman, Analysis of the elemental composition of marine litter by field-portable-XRF. Talanta 159 (2016) 262-271, doi:10.1016/j.talanta.2016.06.026 
[19] M. Filella, A. Turner, Observational study unveils the extensive presence of hazardous elements in beached plastics from Lake Geneva, Front. Environ. Sci. (2018). https://doi.org/10.3389/fenvs.2018.00001.

[20] W. Shotyk, M. Krachler, B. Chen, Contamination of Canadian and European bottled waters with antimony from PET containers, J. Environ. Monit. 8 (2006) 288-292.

[21] H.R. Hansen, S.A. Pergantis, Detection of antimony species in citrus juices and drinking water stored in PET containers, J. Anal. At. Spectrom. 21 (2006) 731-733, doi:10.1039/b606367e/

[22] Council of the European Union, Council Directive 98/83/EC of 3 November 1998 on the quality of water intended for human consumption, Official Journal of the European Communities L 330/32 (1998).

[23] MHPRC (Ministry of Health of the People's Republic of China), Standards for Drinking Water Quality, GB-5749-2006, 2006.

[24] US Federal Water Pollution Control Act. [As Amended Through P.L. 107-303], November 27, 2002.

[25] W. Shotyk, M. Krachler, Contamination of bottled waters with antimony leaching from polyethylene terephthalate (PET) increases upon storage, Environ. Sci. Technol. 41 (2007) 1560-1563, doi:10.1021/es061511

[26] S. Keresztes, E. Tatár, V.G. Mihucz, I. Virág, C. Majdik, G. Záray, Leaching of antimony from polyethylene terephthalate (PET) bottles into mineral water, Sci. Total Environ. 407 (2009) 4731-4735, doi:10.1016/j.scitotenv.2009.04.025

[27] P. Westerhoff, P. Prapaipong, E. Shock, A. Hillaireau, Antimony leaching from polyethylene terephthalate (PET) plastic used for bottled drinking water, Water Res. 42 (2008) 551-556, doi:10.1016/j.watres.2007.07.048

[28] X. Cheng, H. Shi, C.D. Adams, Y. Ma, Assessment of metal contaminations leaching out from recycling plastic bottles upon treatments, Environ. Sci. Pollut. Res. 17 (2010) 13231330, doi:10.1007/s11356-010-0312-4 
[29] C. Reimann, M. Birke, P. Filzmoser, Bottled drinking water: water contamination from bottle materials (glass, hard PET, soft PET), the influence of colour and acidification, Appl. Geochem. 25 (2010) 1030-1046, doi:10.1016/j.apgeochem.2010.04.009

[30] C.A. Chapa-Martínez, L. Hinojosa-Reyes, A. Hernández-Ramírez, E. Ruiz-Ruiz, L. Maya-Treviño, J.L. Guzmán-Mar, An evaluation of the migration of antimony from polyethylene terephthalate (PET) plastic used for bottled drinking water, Sci. Total Environ. 565 (2016) 511-518. doi:10.1016/j.scitotenv.2016.04.184

[31] L. Payán, M.T. Poyatos, L. Muñoz, M.D. La Rubia, , R. Pacheco, N. Ramos, Study of the influence of storage conditions on the quality and migration levels of antimony in polyethylene terephthalate-bottled water, Food Sci. Technol. Int. 23 (2017) 318-327. doi:10.1177/1082013217690300

[32] C.E. Dogan, N. Cebi, Investigation of antimony, cobalt, and acetaldehyde migration into the drinking water in Turkey, Packag. Technol. Sci. 32 (2019) 239-246. doi:10.1002/pts. 2430

[33] V. Roje, P. Sutalo, Trace and major elements in Croatian bottled waters, J. Geochem. Explor. 201 (2019) 79-87. doi:10.1016/j.gexplo.2019.03.015

[34] European Commission, Commission Regulation (EU) No 10/2011 of 14 January 2011 on plastic materials and articles intended to come into contact with food, Official Journal of the European Union L 12/1, 2011.

[35] M. Sánchez-Martínez, T. Pérez-Corona, C. Cámara, Y. Madrid, Migration of antimony from PET containers into regulated EU food simulants, Food Chem. 141 (2013) 816-822, doi:10.1016/j.foodchem.2013.03.067

[36] B.A. Richardson, Cot mattress biodeterioration and SIDS, Lancet 335 (1990) 670, doi:10.1016/0140-6736(90)90463-F

[37] B. A. Richardson, Sudden-infant-dearth-syndrome - A possible primary cause, J. Forensic Soc. 34 (1994) 199-204. doi:10.1016/S0015-7368(94)72915-7 
[38] Council of the European Communities, Council Directive of 3 May 1988 concerning the safety of toys (88/378/EEC), Official Journal of the European Communities L 187/1, 1988.

[39] European Parliament and the Council of the European Union, Directive 2009/48/EC of the European Parliament and of the Council of 18 June 2009 on the safety of toys, Official Journal of the European Union L170/1, 2009.

[40] B. Vriens, A. Voegelin, S.J. Hug, R. Kaegi, L.H.E. Winkel, A.M. Buser, M. Berg, Quantification of element fluxes in wastewaters: a nationwide survey in Switzerland, Environ. Sci. Technol. 51 (2017) 10943-10953, doi:10.1021/acs.est.7b01731

[41] Z. Hu, S. Gao Upper crustal abundances of trace elements: A revision and update, Chem. Geol. 253 (2008) 205-221, doi:10.1016/j.chemgeo.2008.05.010

[42] R. Salminen, M.J. Batista, M. Bidovec, A. Demetriades, B. De Vivo, W. De Vos, M. Duris, A. Gilucis, V. Gregorauskiene, J. Halamic, P. Heitzmann, A. Lima, G. Jordan, G. Klaver, P. Klein, J. Lis, J. Locutura, K. Marsina, A. Mazreku, P.J. O'Connor, S.Å. Olsson, R.T. Ottesen, V. Petersell, J.A. Plant, S. Reeder, I. Salpeteur, H. Sandström, U. Siewers, A. Steenfelt, T. Tarvainen, Geochemical Atlas of Europe, in: R. Salminen (Es.), Part 1: Background Information, Methodology and Maps, Geological Survey of Finland, Espoo, 2005 .

[43] J.R. Jambeck, R. Geyer, C. Wilcox, T.R. Siegler, M. Perryman, A. Andrady, R. Narayan, K. Lavender Law, Plastic waste inputs from land into the ocean, Science 347 (2015) 768-771, doi:10.1126/science.1260352

[44] European Parliament and of the Council 1272/2008 Of December 2008 on classification, labelling and packaging of substances and mixtures, amending and repealing Directives 67/548/EEC and 1999/45/EC, and amending Regulation (EC) No 1907/2006, Official Journal of the European Union L 353.

[45] European Commission, Commission Decision 2014/955/EU of 18 December 2014 amending Decision 2000/532/EC on the list of waste pursuant to Directive 2008/98/EC of the European Parliament and of the Council, Official Journal of the European Union L 370/44 (2014). 
[46] Council of the European Union, Council Regulation (EU) 2017/997 of 8 June 2017 amending Annex III to Directive 2008/98/EC of the European Parliament and of the Council as regards the hazardous property HP 14 'Ecotoxic', Official Journal of the European Union L 150/1, 2017.

[47] P. Hennebert, M. Filella, WEEE plastic sorting for bromine essential to enforce EU regulation, Waste Manage. 71 (2018) 390-399, doi: 10.1016/j.wasman.2017.09.031

[48] European Parliament and the Council of the European Union, Directive 2002/95/EC of the European Parliament and of the Council of 27 January 2003 on the restriction of the use of certain hazardous substances in electrical and electronic equipment, Official Journal of the European Union L 37/19 (2003).

[49] European Parliament and the Council of the European Union, Directive 2011/65 of the European Parliament and of the Council of 8 June July 2011 on the restriction of the use of certain hazardous substances (RoHS) in electrical and electronic equipment (recast), Official Journal of the European Union L174/88 (2011).

[50] European Parliament and the Council of the European Union, Directive 2012/19/EU of the European Parliament and of the Council of 4 July 2012 on waste electrical and electronic equipment (WEEE) (recast), Official Journal of the European Union L 197/38 (2012).

[51] European Commission, Restriuction of Hazardous Substances in Electrical and Electronic Eqiupment: Review of the list of restricted substances. https://ec.europa.eu/environment/waste/rohs_eee/substances_en.htm. Last accessed 11 November 2019.

[52] USEPA, Advancing Sustainable Materials Management: 2015 Fact Sheet. Assessing Trends in Material Generation, Recycling, Composting, Combustion with Energy Recovery and Landfilling in the United States, 2018. https://www.epa.gov/sites/production/files/201807/documents/2015_smm_msw_factsheet_07242018_fnl_508_002.pdf. Last accessed: 26 April 2019.

[53] J. Tang, M. Su, H. Zhang, T. Xiao, Y. Liu, Y. Liu, L. Wei, C. Ekberg, B.M.. Steenari, Assessment of copper and zinc recovery from MSWI fly ash in Guangzhou based on a 
hydrometallurgical process, Waste Manage. 76 (2018) 225-233, doi:10.1016/j.wasman.2018.02.040

[54] A.J. Chandler, T.T. Eighmy, J. Hartlén, O. Hjelmar, D.S. Kosson, S.E. Sawell, H.A. Van der Sloot, J. Vehlow, Municipal Solid Waste Incinerator Residues, Elsevier, Amsterdam, 1997.

[55] R. Götze, A. Boldrin, C. Scheutz, T.F. Astrup, Physico-chemical characterisation of material fractions in household waste: overview of data in literature, Waste Manage. 49 (2016) 3-14, doi:10.1016/j.wasman.2016.01.008

[56] F. Paoletti, S. Pirini, H. Seifert, J. Vehlow, Fate of antimony in municipal solid waste incineration, Chemosphere 42 (2001) 533-543, doi:10.1016/S0045-6535(00)00225-3

[57] T. Sabbas, A. Polettini, R. Pomi, T. Astrup, O. Hjelmar, P. Mostbauer, G. Cappai, G.Magel, S. Salhofer, C. Speiser, H. Seuss-Assbichler, R. Klein, P. Lechner, Management of municipal solid waste incineration residues, Waste Manage. 23 (2003) 61-88, doi:10.1016/S0956-053X(02)00161-7

[58] M. Bäckström, Lakning av antimon från energiaskor - Totalhalter, lakbarhet samt förslag till åtgärder (Leachability of antimony from energy ashes - Total contents, leachability and remedial suggestions) (in Swedish), Värmeforsk report 950, Stockholm, 2006. Available at: https://energiforskmedia.blob.core.windows.net/media/19027/lakning-avantimon-fran-energiaskor-varmeforskrapport-950.pdf (last accessed: 26 April 2019).

[59] K. Nakamura, S. Kinoshita, H. Takatsuki, The origin and behavior of lead, cadmium and antimony in MSW incinerator, Waste Manage. 16 (1996) 509-517, doi:10.1016/S0956053X(96)00093-1

[60] J. Klein, S. Dorge, G. Trouve, D. Venditti, S. Durecu, Behaviour of antimony during thermal treatment of Sb-rich halogenated waste, J. Hazard. Mater. 166 (2009), 585-593, doi:10.1016/j.jhazmat.2008.12.006

[61] N. Watanabe, S. Inoue, H. Ito. Antimony in municipal waste, Chemosphere, 39 (1999) 1689-1698, doi:10.1016/S0045-6535(99)00069-7 
[62] M.J. Quina, E. Bontempi, A. Bogush, S. Schlumberger, G.Weibel, R. Braga, V. Funari, J. Hyks, E. Rasmussen, J. Lederer, Technologies for the management of MSW incineration ashes from gas cleaning: New perspectives on recovery of secondary raw materials and circular economy, Sci. Total Environ. 635 (2018) 526-542, doi:10.1016/j.scitotenv.2018.04.150

[63] Z. Xin-gang, J. Gui-wu, L. Ang, L. Yun, Technology, cost, a performance of wasteto-energy incineration industry in China, Renewable and Sustainable Energy Reviews 55 (2016) 115-130, doi:10.1016/j.rser.2015.10.137

[64] B. Verbinnen, P. Billen, J. Van Caneghem, C. Vandecasteele, Recycling of MSWI bottom ash: A review of chemical barriers, engineering applications and treatment technologies, Waste Biomass Valor. 8 (2017) 1453-1466, doi:10.1007/s12649-016-9704-0

[65] CEWEP, Bottom Ash Fact Sheet. http://www.cewep.eu/2017/09/08/bottom-ashfactsheet/ (2017). Last accessed: 26 April 2019.

[66] H.A. van der Sloot, D.S. Kosson, O. Hjelmar, Characteristics, treatment and utilization of residues from municipal waste incineration, Waste Manage. 21 (2001) 753-765, doi:10.1016/S0956-053X(01)00009-5

[67] G. Cornelis, C.A. Johnson, T. Van Gerven, C. Vandecasteele, Leaching mechanisms of oxyanionic metalloid and metal species in alkaline solid wastes, Appl. Geochem. 23 (2008) 955-976, doi:10.1016/j.apgeochem.2008.02.001

[68] C.H. Jung, T. Matsutoa, N. Tanakaa, T. Okadaa, Metal distribution in incineration residues of municipal solid waste (MSW) in Japan, Waste Manage. 24 (2004) 381-391, doi:10.1016/S0956-053X(03)00137-5

[69] L. Zhao, F-S. Zhang, K. Wang, J. Zhu. Chemical properties of heavy metals in typical hospital waste incinerator ashes in China. Waste Manage. 29 (3) (2009) 1114-1121, doi:10.1016/j.wasman.2008.09.003

[70] H. Wang, Z. Lv, B. Wang, Y.N. Wang, Y. Sun, Y.F. Tsang, Y.J. Sun, Y.F. Tsang, J.W. Zhao, M. Zhan, Effective stabilization of antimony in Waste-to-Energy fly ash with recycled laboratory iron-rich residuals, J. Cleaner Production 230 (2019) 685-693. doi:10.1016/j.jclepro.2019.05.128 
[71] Council of the European Union, Council Decision of 19 December 2002 establishing criteria and procedures for the acceptance of waste at landfills pursuant to Article 16 of and Annex II of Directive 1999/31/EC, Official Journal of the European Communities L 11/27 (2003).

[72] NOAH, Data from internal database, NOAH, Holmestrand, Norway, 2018. Personal communication Sverre Koren.

[73] G. Okkenhaug, G.D. Breedveld, T. Kirkeng, M. Laegreid, T. Maehlum, J. Mulder, Treatment of air pollution control residues with iron rich waste sulfuric acid: Does it work for antimony (Sb)? J. Hazard. Mater. 248 (2013) 159-166, doi:10.1016/j.jhazmat.2012.12.041

[74] NRF (Norsk Renholdsverk Forening), Prøvetakning og analyse av bunnaske fra forbrenning av avfall. (Sampling and analysis of bottom ash from waste incineration) (In Norwegian). Report 2/2006, 2006.

http://avfallnorge.web123.no/article_docs/NRF\%20rapport\%20nr\%2022006\%20Bunnaske\%20fra\%20avfallsforbrenning.pdf (last accessed: 28 April 2019)

[75] R. Pettersson, P, Suér, J. Rogbeck, Pannsand som fyllnadsmaterial för fjärrvärmerörgravar. Kemisk och geoteknisk karakterisering av fluidbäddsand ("Bottom ash from fluidised bed boilers as filler material in district heating pipe culverts. Chemical and geotechnical characterisation”) (in Swedish), Värmeforsk report 852, 2004. Available at: https://energiforskmedia.blob.core.windows.net/media/19594/pannsand-somfyllnadsmaterial-for-fjarrvarmerorgravar-varmeforskrapport-852.pdf (last accessed: 29 April 2019).

[76] J.A. Meima, R.N.J. Comans, Reducing Sb-leaching from municipal solid waste incinerator bottom ash by addition of sorbent minerals, J. Geochem. Explor. 62 (1998) 299304, doi:10.1016/S0375-6742(97)00044-7

[77] F.G. Simon, U. Kalbe, N. Bandow, Potential use of incineration bottom ash in construction - Evaluation of the environmental impact. Conference proceeding, WASCON 2018, 10th International Conference on the Environmental and Technical Implications of Construction with alternative materials, Tampere, 6-8 June 2018. 
[78] H. Tian, J.R. Zhou, C. Zhu, D. Zhao, J. Gao, J. Hao, M. He, K. Liu, K. Wang, S. Hua, A Comprehensive global inventory of atmospheric antimony emissions from anthropogenic activities, 1995-2010, Environ. Sci. Technol. 48 (2014) 10235-10241, doi:10.1021/es405817u

[79] G. Okkenhaug, A.R. Almås, N. Morin, S. Hale, H.P.H. Arp, The presence and leachability of antimony in different wastes and waste handling facilities in Norway, Environ. Sci. Processes Impacts 17 (2015) 1880-1891, doi:10.1039/C5EM00210A

[80] P. Kiddee, R. Naidu, M.H. Wong, L. Hearn, J.F. Muller, Field investigation of the quality of fresh and aged leachates from selected landfills receiving e-waste in an arid climate, Waste Manage. 34 (2014) 2292-2304, doi:10.1016/j.wasman.2014.06.018

[81] NIBIO, Data from internal database NIBIO, Aas, Norway, 2019. Personal communication Trond Mahlum.

[82] C. Öman, M. Malmberg, C. Wolf-Watz, Utveckling av metoder för karakterisering av lakvatten från avfallsupplag - Slutrapport (Developement of methods for characterization of landfill leachate - Final report) (in Swedish), IVL Rapport/report B 1353, 2000. Available at: www.ivl.se/download/18.343dc99d14e8bb0f58b7391/1445515426870/B1353.pdf (last accessed: 28 April 2019)

[83] M.O. Looser, A. Parriaux, M. Bensimon, Landfill underground pollution detection and characterization using inorganic traces, Water Res. 33 (1999) 3609-3616, doi:10.1016/S0043-1354(99)00062-7

[84] M. El-Fadel, E. Bou-Zeid, W. Chahine, B. Alayli, Temporal variation of leachate quality from pre-sorted and baled municipal solid waste with high organic and moisture content, Waste Manage. 22 (2002) 269-282, doi:10.1016/S0956-053X(01)00040-X 
Figure captions

Figure 1. A flow chart showing the use and fate of $\mathrm{Sb}$ in plastics. Note that the blue area shows the scope of our study and that the possible recycling of bottom ashes is not included in the schema.

Figure 2. World antimony production over the past 120 years. Source:

https://minerals.usgs.gov/minerals/pubs/commodity/antimony/

Figure 3. XRF spectra for yellow ABS Lego bricks manufactured in about (a) 1995 and (b) 1980.

Figure 4. Reported $\mathrm{Sb}$ consumption in the US from the USGS Mineral Yearbooks (https://minerals.usgs.gov/minerals/pubs/commodity/antimony/). (a) Reported uses classified as metal, flame retardant and non-metal uses other than flame retardant from 1943 to 2016. (b) Reported Sb consumption in flame retardants classified by uses from 1974 to 2016. Values before 1980 were in short $\mathrm{t}$ and have been converted here to metric $\mathrm{t}$. The consumption values in the Mineral Yearbooks are based on the voluntary responses received from the industry to USGS surveys.

Figure 5. Box-whisker-plots and data points for antimony concentrations in different waste material fractions reported in literature. The displayed whiskers correspond to the upper quartile plus the interquartile range multiplied by a factor of 1.5 and the lower quartile minus the interquartile range multiplied by a factor 1.5. All values beyond these points are considered as outliers. Source: [54], Appendix B.

Figure 6: Antimony concentrations in fly ash from waste incineration in Norway, Sweden and Denmark (time period 2006 - 2017). XRF data from NOAH, Langøya $(n=1993)$.

Figure 7: Antimony concentrations in untreated and treated (on-site) municipal landfill leachate from three Norwegian municipal waste landfills (A-C) that have been operated for approximately 40 years (1968 - 2008) [68]. The mean and standard deviation is given in each case. 
Figure 1

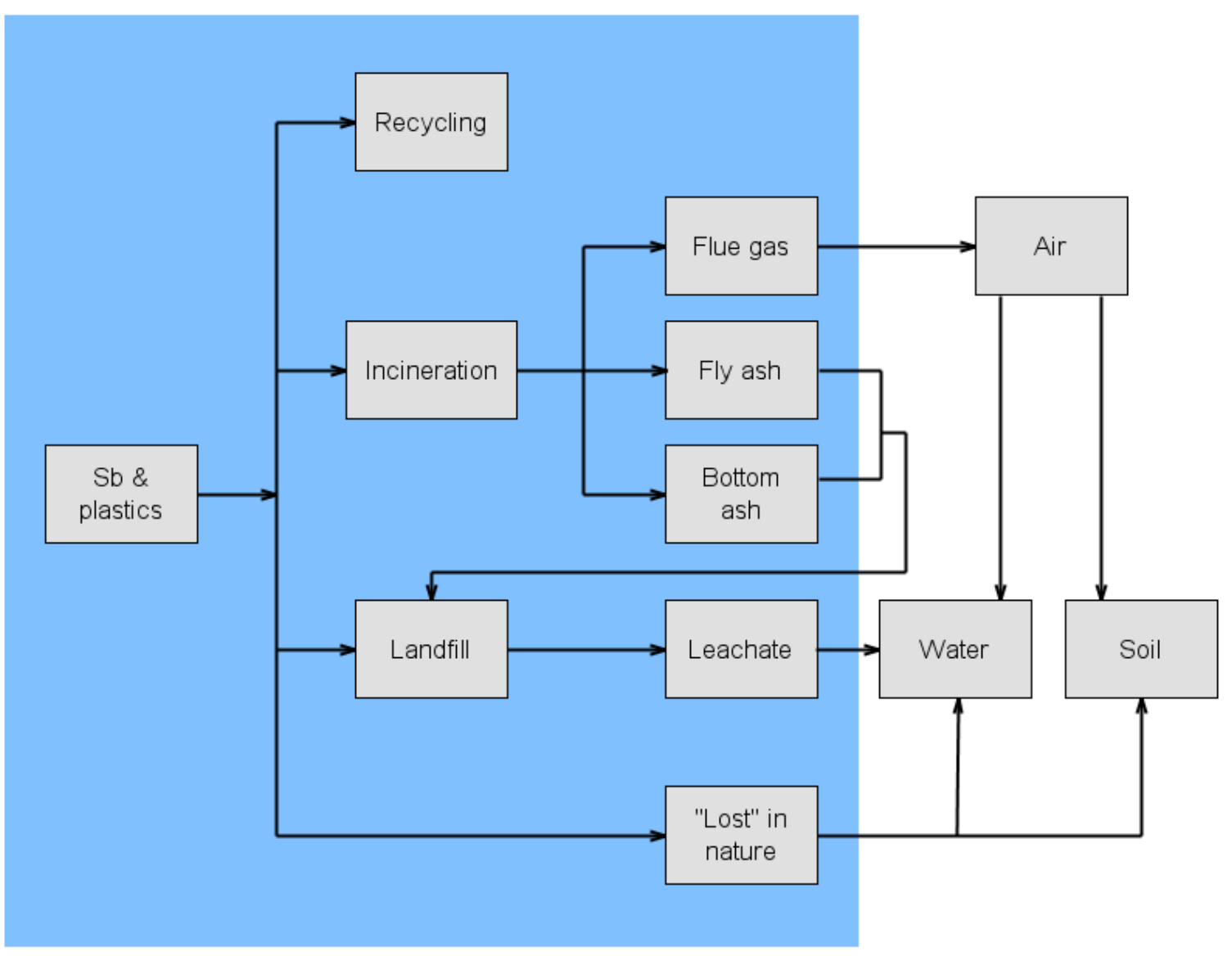


Figure 2

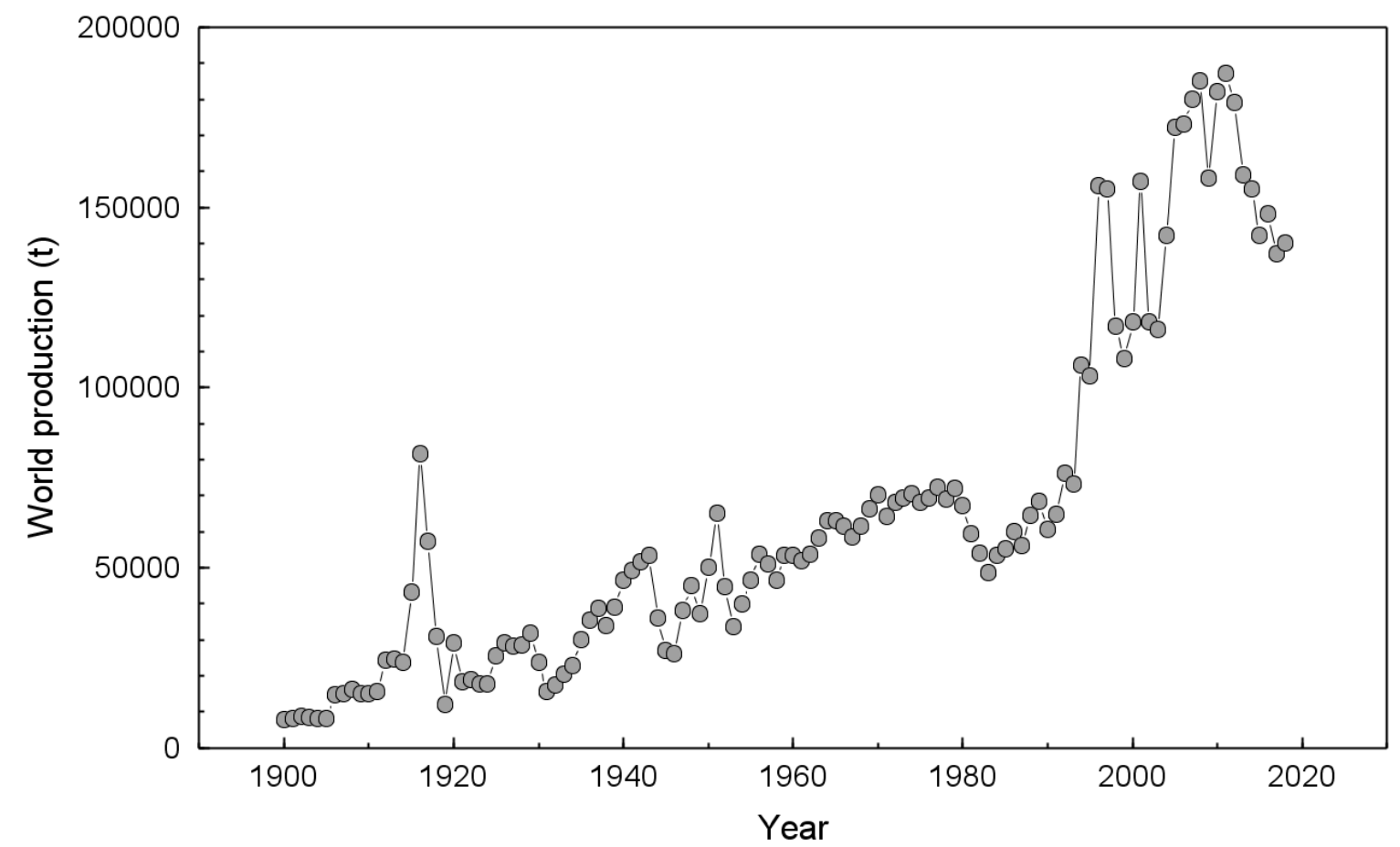


Figures $3 \mathrm{a}$ and $3 \mathrm{~b}$

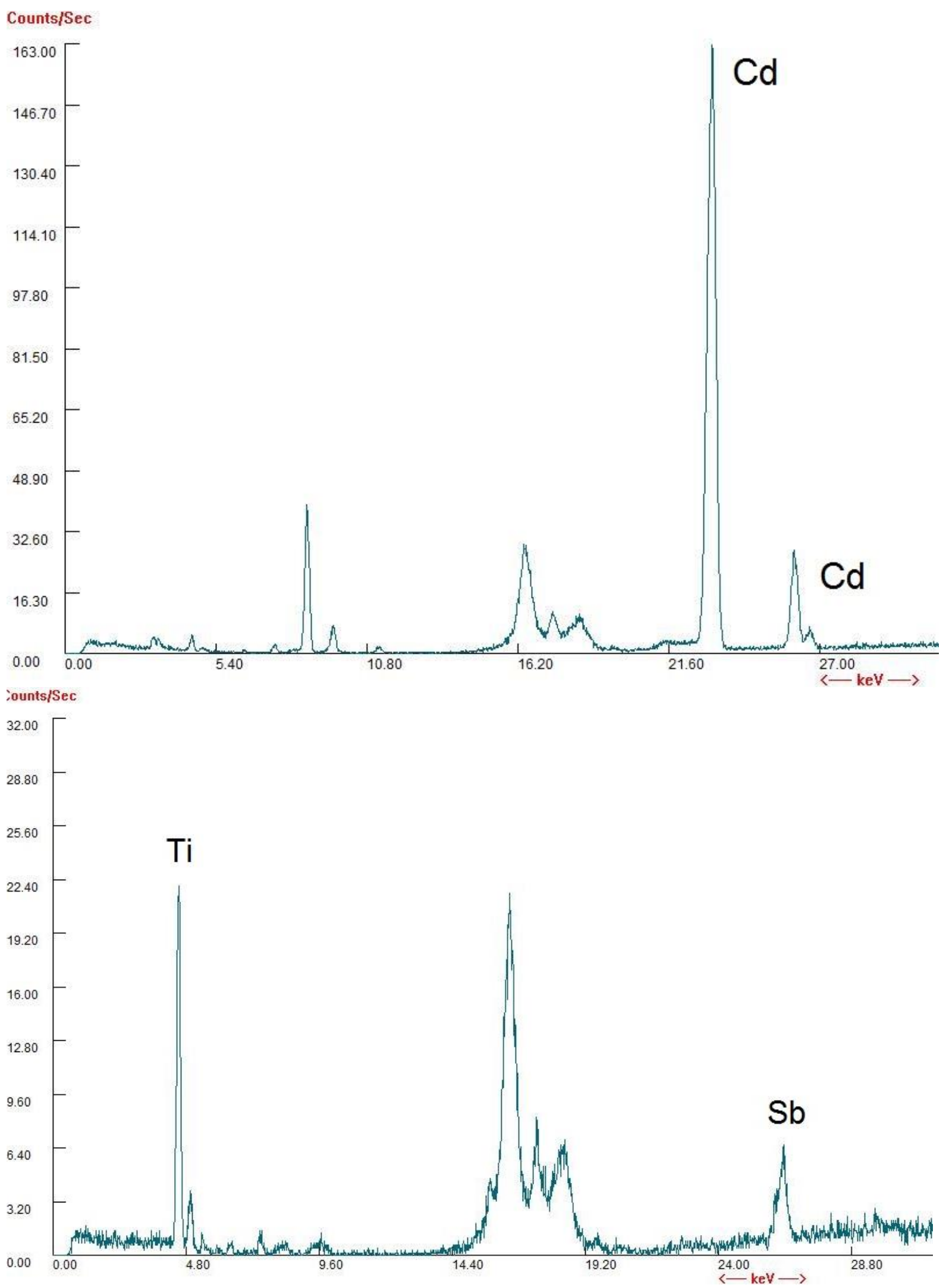


Figure 4a

Flame retardants

Non-metal products other than flame-retardants

Metal products

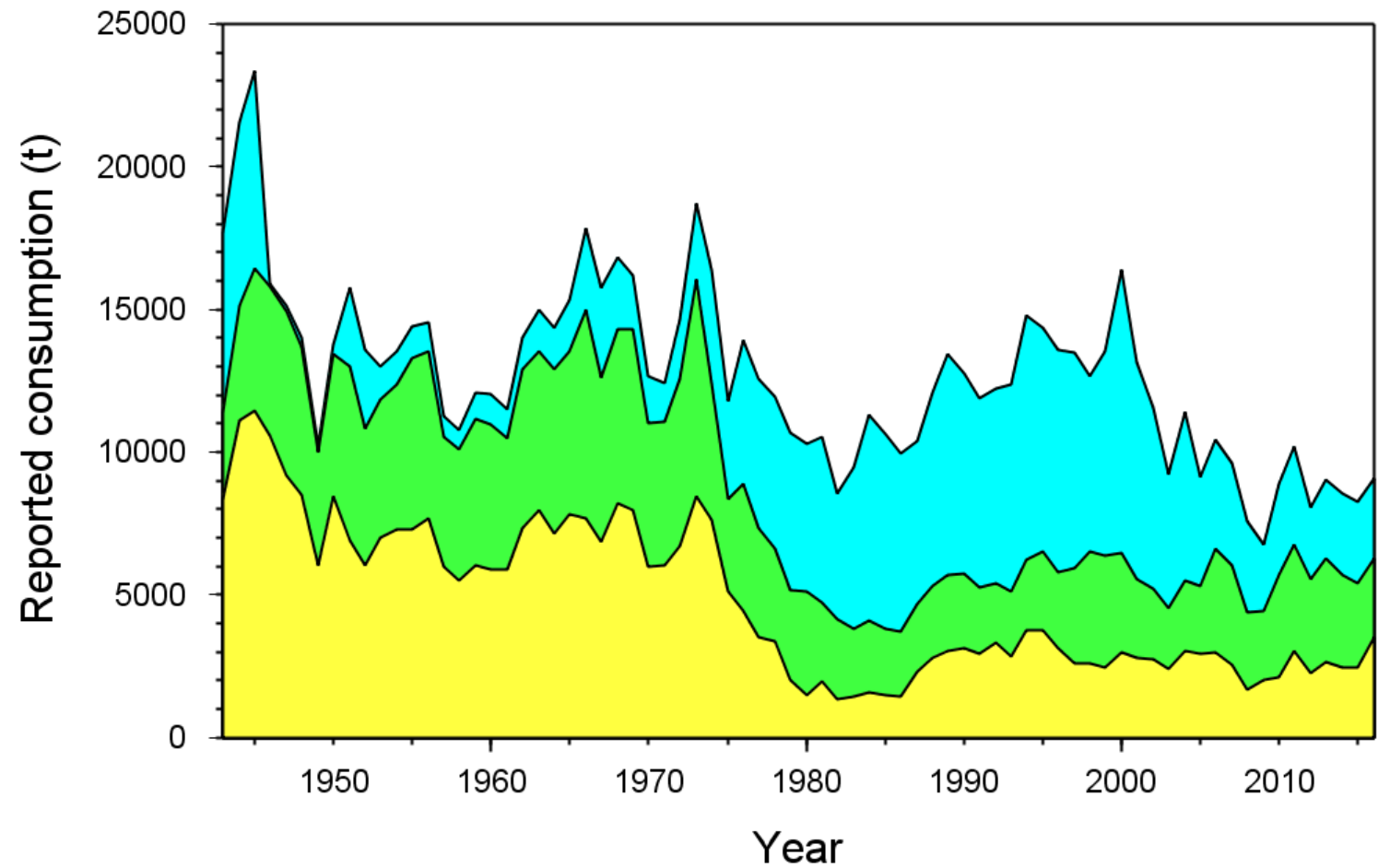


Figure $4 b$

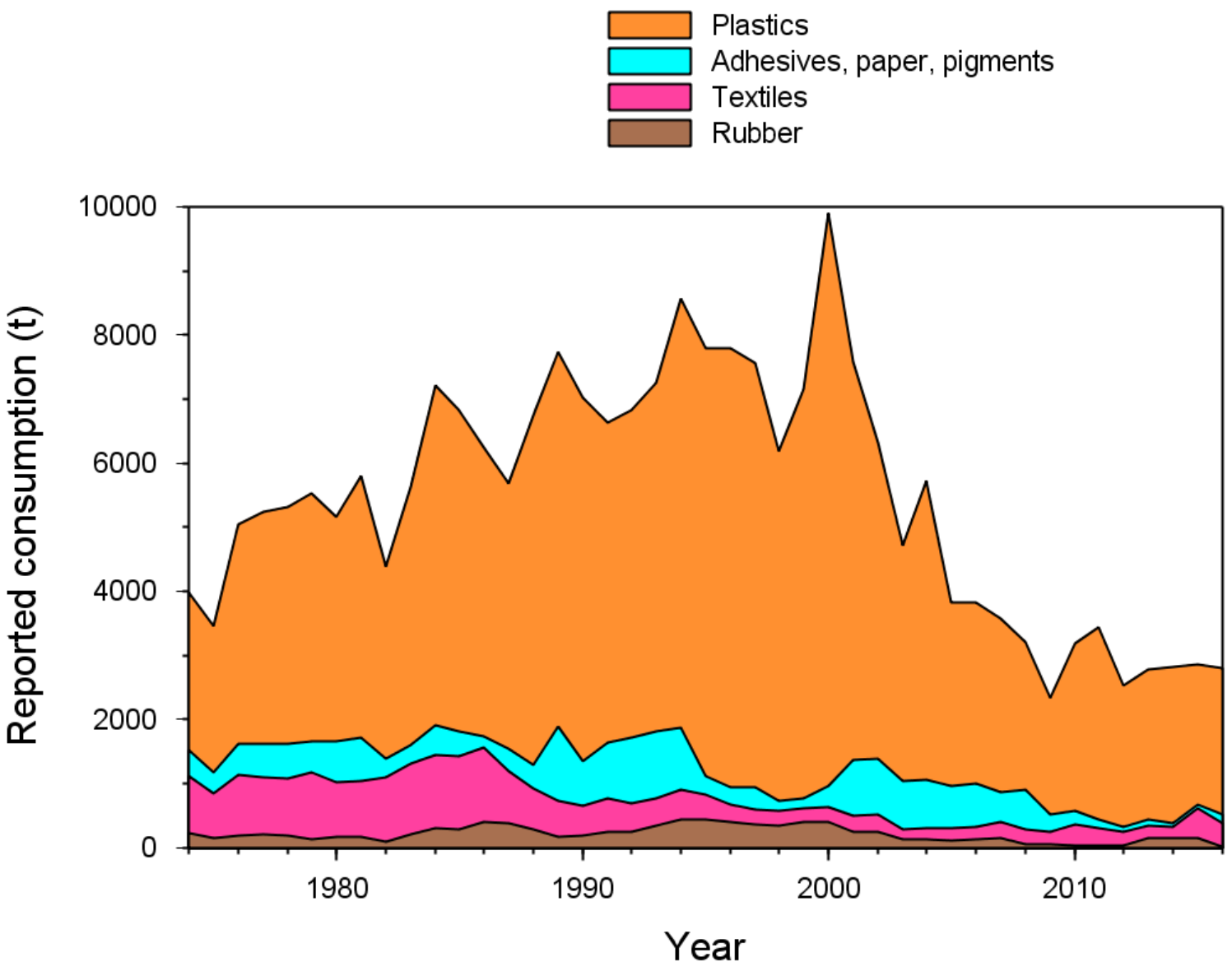


Figure 5

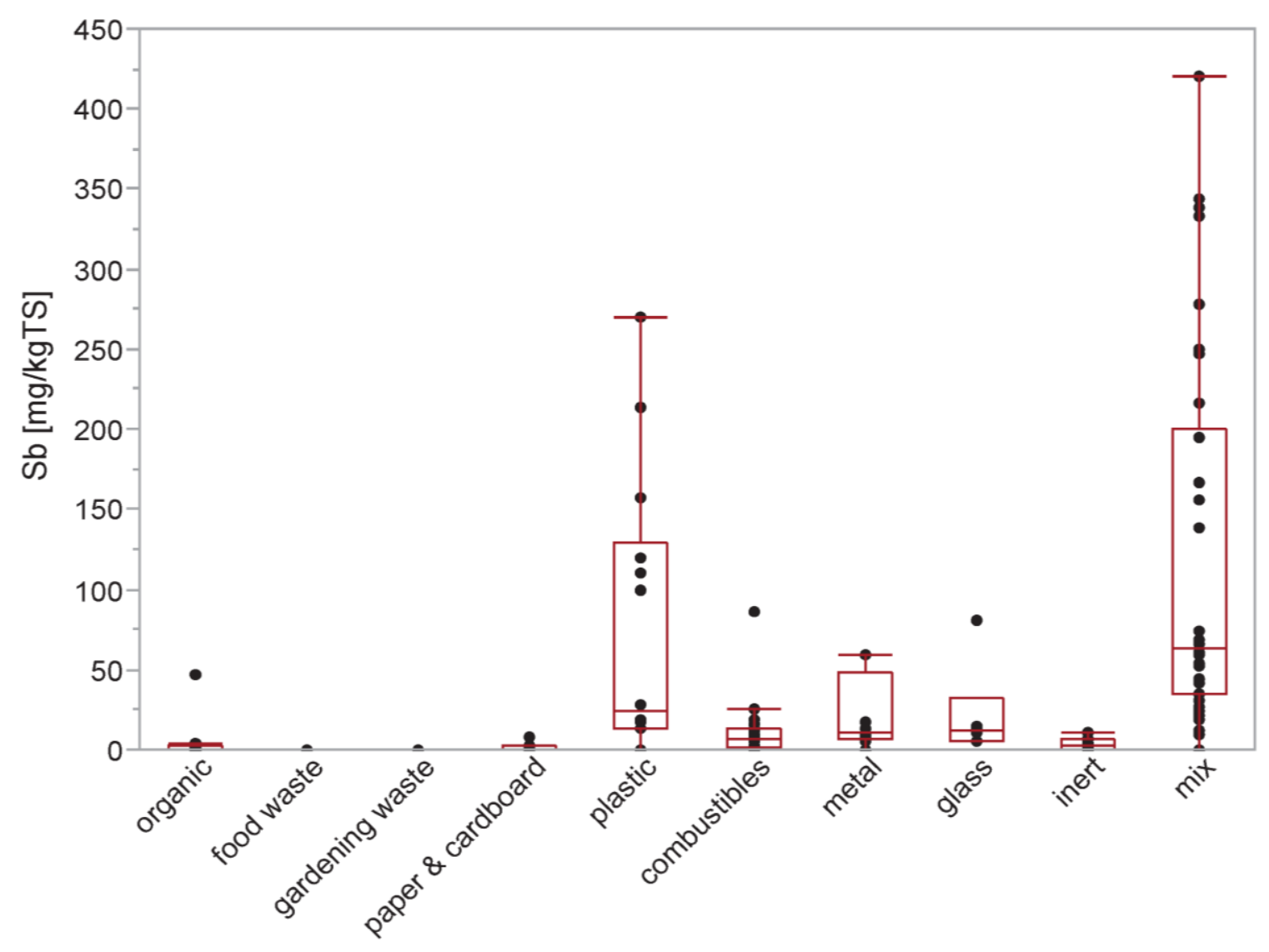

Waste Material Fractions 
Figure 6

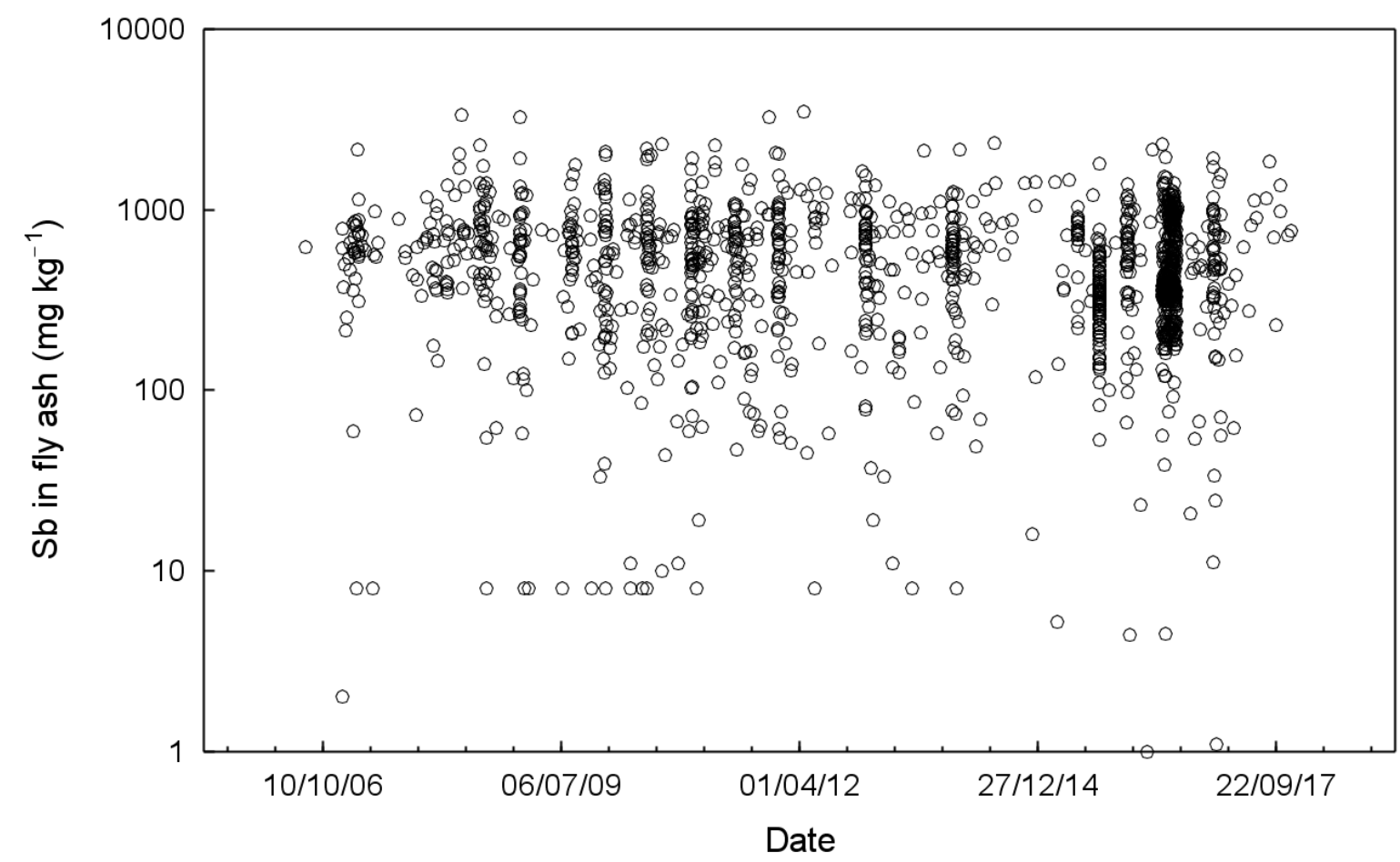


Figure 7

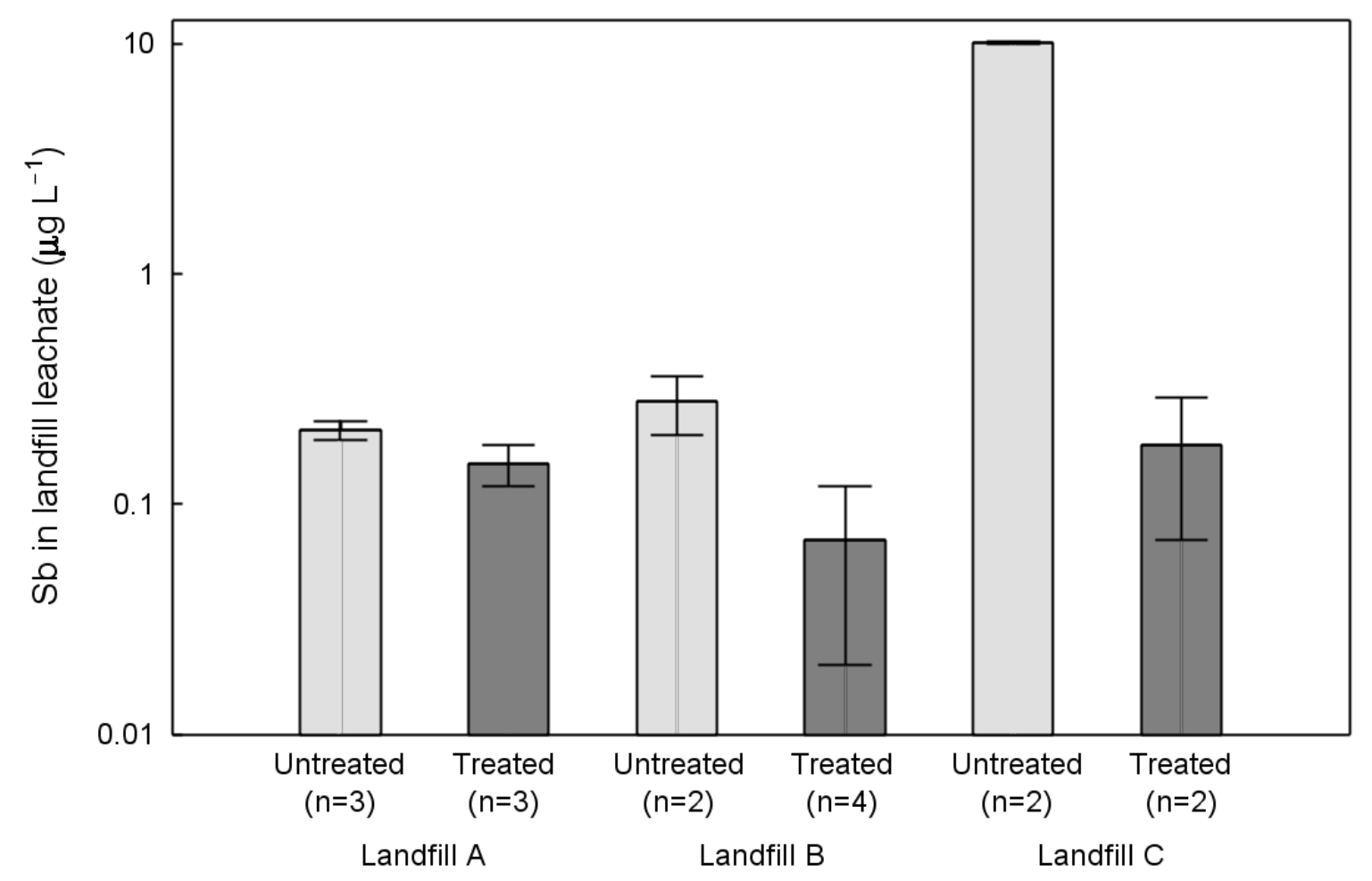


Table 1: Typical concentration range of Sb encountered in different types of plastic product, along with its co-association with Br, representative plastic colours and specific product examples.

\begin{tabular}{|c|c|c|c|c|}
\hline & $\mathrm{Sb}, \mathrm{mg} \mathrm{kg}^{-1}$ & $\mathrm{Br}, \mathrm{mg} \mathrm{kg}^{-1}$ & colours & examples \\
\hline PET catalytic residue & $100-800$ & absent & any & food trays, water bottles, clothing, curtains, rucksacks \\
\hline coloured pigment & $500-2000$ & absent & $\begin{array}{l}\text { yellow, brown, } \\
\text { green }\end{array}$ & toys, games, office equipment, watering cans \\
\hline $\begin{array}{l}\text { synergist in electrical equipment } \\
\text { (non-PVC) }\end{array}$ & $>5000$ & $>5000$ & mainly neutral & chargers, heaters, remote controls, circuit boards, lighbulb collars \\
\hline synergist in PVC & $>5000$ & absent & mainly neutral & plugs, wire insulation, usb connectors, hosing, piping \\
\hline recycled from electrical equipment & $50-3000$ & $50-5000$ & mainly neutral & $\begin{array}{l}\text { office equipment, toys, beads, tool handles, new electrical products } \\
\text { food-contact items }\end{array}$ \\
\hline
\end{tabular}

